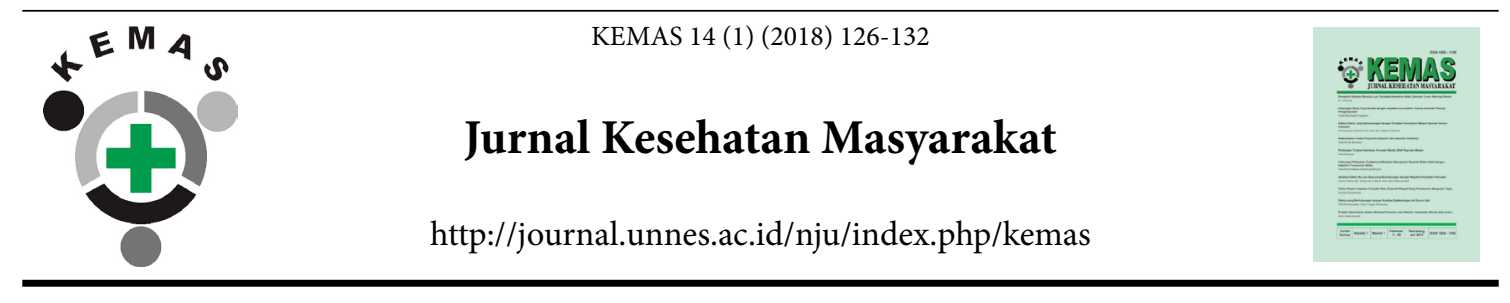

\title{
The Change of Knowledge and Attitude of Bride and Groom Candidate After Reproductive Health Pre-Marital Course by KUA Officer
}

\author{
Sri Achadi Nugraheni ${ }^{1}$, Martini ${ }^{1}$, M I Kartasurya ${ }^{1}$, I Johan ${ }^{2}$, Reni Prawestuti Ambari ${ }^{3 凶}$, \\ E Sulistiawati ${ }^{1}$, I Nurchumaida $^{1}$ \\ ${ }^{1}$ Public Health Faculty Diponegoro University, Indonesia \\ ${ }^{2}$ Health Science Faculty, Pesantren Tinggi Darul Ulum University, Indonesia \\ ${ }^{3}$ Educational Science Faculty, Universitas Negeri Semarang, Indonesia
}

\section{Article Info}

\section{Article History:}

Submitted March 2018

Accepted June 2018

Published July 2018

Keywords:

Pre Marriege Course, Bride and Groom Candidate,

Reproductive Health, KUA

DOI

https://doi.org/10.15294/

kemas.v14i1.13495

\begin{abstract}
Reproductive health in Indonesia is still very poor, as evidenced by the still high maternal mortality rate (MMR). MMR decline was slow, as well as in the province of Central Java. The highest is in Brebes Regency which has as many as 53 cases of maternal decease. One of the causes of high MMR is the lack of reproductive health sensitivity of bride and groom candidates. The purpose of this research is to analyze the influence of counseling on bride and groom candidates knowledge and attitude related to reproductive health. This research is a quasi experimental research with pre and post test without control group design. The population was bride and groom candidates listed in KUA of Brebes Regency in July and August of 2017, with a sample of 100 pairs selected according to the inclusion criteria. The interventions in the form of a one-day course by KUA officers on reproductive health with Bride and Groom Candidates Reproductive Healt booklet and flipcharts as the tools. The data of knowledge and attitude are obtained by interviewing the bride and groom candidates. Analysis is conducted with Wilcoxon Match Paired Test. The results showed that there is a difference of bride and groom candidates knowledge and attitude before and after intervention $(\mathrm{p}<0,05)$, with mean value increased 2.58 points (knowledge) and 3,21 points (attitude). Recommended advised are the pre-marital program socialized by KUA officers is expanded and multiplication of the booklet as a tool for the officers in pre-marital courses implementation.
\end{abstract}

\section{Introduction}

Reproductive health in Indonesia is still an apprehensive matter. Based on the 2007 IDHS survey (1994-2007), the MMR is still at 228 per 100,000 live births and in 2012 at 359 per 100,000 live births, whereas the $2015 \mathrm{MDG}$ target is to reduce MMR to 102 per 100,000 live births and the target seems to fail to meet. Observing the slow downward trend of MMR, it is feared that the target of SDGs will not be reached. In 2014 the absolute mortality rate in Indonesia reaches 4925 and in 2015 was 4809 .
2015 Central Java health profile indicated that case of deceased mother was 619 cases with MMR 111.16, while highest number in Central Java is on Brebes Regency with 53 cases of deceased mother (Kementerian Kesehatan RI, 2017).

Maternal decease usually occur because they do not have access to quality maternal health services, especially emergency obstetric services due to late identification of warning signs and decisions, late arrivals at health facilities, and late service in health facilities. 
Furthermore, the cause of maternal decease is also inseparable from the mother's condition itself and is one of the 4 "too" criteria, too old at delivery (over 35 years), too young at delivery (less than 20 years), too many children (more than 4 children), too close birth/parity interval (less than 2 years). Sixty-five per cent of maternal decease occurrs at the time of childbirth, at the time of pregnancy of 26.33 per cent, and at the time of delivery of 12.76 per cent. Causes of death are such as bleeding, hypertension, infections and disorders of the circulatory system. Based on the age group, the highest incidence of maternal deaths was in the age of 20-34 years 68.50 percent, then in the age group over 35 years 26.17 percent and in the age group less than 20 years 5.33 percent (Kementerian Kesehatan RI, 2017).

High MMR and all the problem can be caused by the lack of reproductive health education. Reproductive health education has existed in various programs such as youth care service program (PKPR) contributing to adolescents related to knowledge, attitude and activities in maintaining reproductive health in Buleleng sub-district (Wijaya, 2014). The MMR decrease effort needs a great innovation that is supported by many parties. The chain of maternal decease is very possible to be disconnected or prevented from the beginning by taking into account the life cycle of expectant mothers with regard to sexual behavior. The interaction between the expectant mother and the surrounding individual has a major influence to prevent inappropriate sexual behavior (Azinar, 2013). One effective effort is to empower the Office of the Ministry of Religious Affairs in this case the Extension Officers in the religious affairs office (KUA) as individuals who deal directly with the prospective bride. The innovative pre-marital course is one of the strategic actions that have significant leverage for problem solving that improve mother's knowledge to minimize the cause of decease during pregnancy, labor and immediately after childbirth. This is also in line with one of the goals of sustainable development until the year 2030 is about the reduction of MMR, considering that the next generation is determined by the quality of maternal and child health, among others, by improving the reproductive health quality of the bride and groom.

The purpose of this research is to analyze the difference of knowledge and attitude of the bride candidate related to reproductive health before and after being given intervention in the area of Office of Religious Affairs of Brebes Regency.

\section{Method}

The research uses quantitative approach, with pre and post test design in one group without control. Interventions were given for a day (3 to 4 hours) of a pre-marital Reproductive Health Course on KUA prepared by a previously trained KUA Officer. The course tools are the reproductive health booklets and feedback sheets for the bride and groom candidate. The target of the intervention is the bride and groom candidate registered in the KUA of Brebes District in July-August 2017. Samples are selected purposively as many as 100 candidates according to the inclusion criteria, which are willing to attend and not pregnant at the time of the course. At the beginning and end of the research, the measurement of knowledge and attitudes of bride and groom related to their behavior about reproductive health and the preparation of family life and prevention of MMR and IMR. The data is taken with interview technique with structured questionnaires that have been tested the validity and reliability. Data analysis was conducted by Wilcoxon match paired test.

\section{Result and Discussion}

Research with bride and groom candidates respondents registered in KUA Kabupaten Brebes in July and August of 2016 has the following characteristics: most of the respondents were women $(61.0 \mathrm{t} \%)$, bride and groom candidates age were mostly between 21 35 years $(75.0 \%)$, with the youngest was 17 years old and the oldes was 38 years old. Education of bride and groom candidates, majority of the respondents have graduated from junior high school or equal $(32.0 \%)$, all bride and groom work mostly as employee in private sector (67\%), whether the bride or the groom.

The implementation of pre-marital courses provided by KUA officers for 3-4 hours includes knowledge related to maintaining reproductive health, free sex before marriage 
prohibition, tetanus immunization, reproductive organs, SEZ handling, ideal pregnancy, contraception, contraception use plan, fetal development process, late menstruation, pregnancy test, blood pressure measurement, added blood tablet, pregnant women avoid cigarette smoke, and risky pregnancy, performed for one day.

The result of Wilcoxon test shows that there is difference of knowledge of bride and groom candidate before and after intervention in the form of pre-marital course by KUA officer with $p$ value $=0,001(p<0.05)$, increase of average value equal to 2.58 points.

There is an increasing knowledge of the bride and groom especially about premarital preparation, nutrition preparation and reproductive organs. This is aligned with research which states that pre-marital education can improve knowledge about reproductive health and couples' readiness significantly for bride and groom candidate (Keshavarz et al., 2013). Respondent knowledge regarding the ideal pregnancy and unwanted pregnancy are also improved. This is in accordance with the recommendation of The International Federation of Gynecology and Obstetrics (FIGO) that adolescents, preconception partners, women preparing for pregnancy, require knowledge preparation on health, particularly about optimum nutrition. Adequate nutrition before preconception is the key to achieve healthy pregnancy, delivery and postpartum. Thus a healthy pregnancy, exclusive breastfeeding success, embryonic growth, fetus and healthy baby can be achieved (Hanson, 2015).

Respondents' knowledge of pregnancy tests, pregnant women should not be exhausted and risky pregnancy are increased after pre-marital courses. Studies by Greenaway also stated that pre-marital education in Sub-Saharan Africa can improve readiness, women's knowledge of the first marriage, and pregnancy preparation. Women who have had reproductive health education are safer than women who have not been exposed to reproductive health education in preparing for their pregnancies (Smith, 2016). The bride and groom have problems at the beginning of the marriage due to the limited knowledge about having own family and reproductive health, so this period is appropriate to provide education as an effort to improve health status (Giarratano et al., 2010).

Differences of the bride and groom candidate attitude before and after intervention in the form of pre-marital course with $\mathrm{p}$ value $=$ $0,001(p<0.05)$ and increase of average value to 3.21 points. Based on the research, respondents have positive attitude regarding reproductive health knowledge, have sex with unauthorized spouse, contraception method usage, pregnancy plan, TT injection, cigarette smoke, pregnant woman's diet, pregnant woman's meal portion, PMS examination, pregnancy warning sign, pregnancy gymnastic, pregnancy examination, and wanted pregnancy. As the knowledge, attitudes consist of various actions, such as receiving, responding, valuing, and being responsible (Rizki, 2012). This indicates that pre-marital course can improve the knowledge, readiness and attitude of the bride and groom candidate. Pre-marital course through discussion class can improve the knowledge, readiness, attitude and behavior of the bride and groom candidate. Through counseling and media tool can minimize the incidence of mortality during pregnancy, delivery to postpartum (Brixval et al., 2016).

Premarital education regarding mother and child health promotion on pre pregnancy, morbidity preventive efforts, complications and mortality incident for the bride and groom, including contraception usage plan, are a strategic effort for social protection to create prosperous and qualified families (Al-Sulaiman et al., 2008; Alswaidi \& Sarah, 2009; Ibrahim et al., 2011; Al-Azeem, 2011). Pre-marital education can prevent the occurrence of illness, and preventive efforts to improve mother and baby health (Al-Azeem, 2011). Based on Beamish's review in Ibrahim et al., (2013), free sex before marriage increases the risk of sexually transmitted disease infection. It stated that the bride and groom are in great need of reproductive health information, because it is included in the critical phase in the preparation of pregnancy, childbirth, postpartum and the health of the baby (Ibrahim et al., 2013).

The respondents showed a negative attitude to reproduction organ abnormalities 
Table 1. The difference of bride and groom candidate knowledge

\begin{tabular}{|c|c|c|c|c|}
\hline \multirow{2}{*}{ Variable } & \multicolumn{2}{|c|}{ Before } & \multicolumn{2}{|c|}{ After } \\
\hline & $\mathrm{N}$ & $\%$ & $\mathrm{~N}$ & $\%$ \\
\hline \multicolumn{5}{|c|}{ How to take care reproductive health } \\
\hline Know & 57 & 57,0 & 93 & 93,0 \\
\hline Doesn't know & 43 & 43,0 & 7 & 7,0 \\
\hline \multicolumn{5}{|c|}{ Pre-marital free sex prohibition } \\
\hline Know & 24 & 24,0 & 32 & 32,0 \\
\hline Doesn't know & 76 & 76,0 & 68 & 68,0 \\
\hline \multicolumn{5}{|c|}{ Tetanus Immunization } \\
\hline Know & 46 & 46,0 & 54 & 54,0 \\
\hline Doesn't know & 54 & 54,0 & 46 & 46,0 \\
\hline \multicolumn{5}{|c|}{ Reproductive Organs } \\
\hline Know & 88 & 88,0 & 99 & 99,0 \\
\hline Doesn’t know & 12 & 12,0 & 1 & 1,0 \\
\hline \multicolumn{5}{|l|}{ SEZ Handling } \\
\hline Know & 68 & 68,0 & 91 & 91,0 \\
\hline Doesn't know & 32 & 32,0 & 9 & 9,0 \\
\hline \multicolumn{5}{|c|}{ Ideal Pregnancy } \\
\hline Know & 87 & 87,0 & 100 & 100,0 \\
\hline Doesn't know & 13 & 13,0 & 0 & 0,0 \\
\hline \multicolumn{5}{|l|}{ Contraception } \\
\hline Know & 46 & 46,0 & 37 & 37,0 \\
\hline Doesn't know & 54 & 54,0 & 63 & 63,0 \\
\hline \multicolumn{5}{|c|}{ Contraception Use Plan } \\
\hline Know & 76 & 76,0 & 94 & 94,0 \\
\hline Doesn't know & 24 & 24,0 & 6 & 6,0 \\
\hline \multicolumn{5}{|c|}{ Fetal Development Process } \\
\hline Know & 47 & 47,0 & 72 & 72,0 \\
\hline Doesn't know & 53 & 53,0 & 28 & 28,0 \\
\hline \multicolumn{5}{|c|}{ Late Menstruation } \\
\hline Know & 32 & 32,0 & 73 & 73,0 \\
\hline Doesn’t know & 68 & 68,0 & 27 & 27,0 \\
\hline \multicolumn{5}{|l|}{ Pregnancy Test } \\
\hline Know & 88 & 88,0 & 96 & 96,0 \\
\hline Doesn't know & 12 & 12,0 & 4 & 4,0 \\
\hline \multicolumn{5}{|c|}{ Blood Pressure Measurement } \\
\hline Know & 76 & 76,0 & 100 & 100,0 \\
\hline Doesn't know & 24 & 24,0 & 0 & 0,0 \\
\hline \multicolumn{5}{|c|}{ Added Blood Tablet } \\
\hline Know & 76 & 76,0 & 93 & 93,0 \\
\hline Doesn't know & 24 & 24,0 & 7 & 7,0 \\
\hline \multicolumn{5}{|c|}{ Pregnant Women Avoid Cigarette Smoke } \\
\hline Know & 79 & 79,0 & 100 & 100,0 \\
\hline Doesn't know & 21 & 21,0 & 0 & 0,0 \\
\hline \multicolumn{5}{|c|}{ Risky Pregnancy } \\
\hline Know & 77 & 77,0 & 91 & 91,0 \\
\hline Doesn't know & 23 & 23,0 & 9 & 9,0 \\
\hline
\end{tabular}


Table 2. Bride and Groom Candidate Attitude Change

\begin{tabular}{|c|c|c|c|c|}
\hline \multirow{2}{*}{ Variable } & \multicolumn{2}{|c|}{ Before } & \multicolumn{2}{|c|}{ After } \\
\hline & $\mathrm{N}$ & $\%$ & $\mathrm{~N}$ & $\%$ \\
\hline \multicolumn{5}{|c|}{ Reproductive health knowledge } \\
\hline Agree & 80 & 80,0 & 100 & 100,0 \\
\hline Not Agree & 20 & 20,0 & 0 & 0,0 \\
\hline \multicolumn{5}{|c|}{ Have sex with unauthorized spouse } \\
\hline Agree & 24 & 24,0 & 32 & 32,0 \\
\hline Not Agree & 76 & 76,0 & 68 & 68,0 \\
\hline \multicolumn{5}{|c|}{ Reproduction organ abnormality } \\
\hline Agree & 72 & 72,0 & 61 & 61,0 \\
\hline Not Agree & 28 & 28,0 & 39 & 39,0 \\
\hline \multicolumn{5}{|c|}{ Contraception method usage } \\
\hline Agree & 53 & 53,0 & 77 & 77,0 \\
\hline Not Agree & 47 & 47,0 & 23 & 23,0 \\
\hline \multicolumn{5}{|c|}{ Pregnancy plan } \\
\hline Agree & 38 & 38,0 & 86 & 86,0 \\
\hline Not Agree & 62 & 62,0 & 14 & 14,0 \\
\hline \multicolumn{5}{|c|}{ TT Injection } \\
\hline Agree & 73 & 73,0 & 95 & 95,0 \\
\hline Not Agree & 27 & 27,0 & 5 & 5,0 \\
\hline \multicolumn{5}{|c|}{ Cigarette smoke } \\
\hline Agree & 72 & 72,0 & 96 & 96,0 \\
\hline Not Agree & 28 & 28,0 & 4 & 4,0 \\
\hline \multicolumn{5}{|c|}{ Pregnant woman's diet } \\
\hline Agree & 52 & 52,0 & 90 & 90,0 \\
\hline Not Agree & 48 & 48,0 & 10 & 10,0 \\
\hline \multicolumn{5}{|c|}{ Prohibition during pregnancy } \\
\hline Agree & 17 & 17,0 & 24 & 24,0 \\
\hline Not Agree & 83 & 83,0 & 76 & 76,0 \\
\hline \multicolumn{5}{|c|}{ Pregnant woman's meal portion } \\
\hline Agree & 69 & 69,0 & 97 & 97,0 \\
\hline Not Agree & 31 & 31,0 & 3 & 3,0 \\
\hline \multicolumn{5}{|c|}{ PMS Examination } \\
\hline Agree & 59 & 59,0 & 93 & 93,0 \\
\hline Not Agree & 41 & 41,0 & 7 & 7,0 \\
\hline \multicolumn{5}{|c|}{ Pregnancy warning sign } \\
\hline Agree & 88 & 88,0 & 93 & 93,0 \\
\hline Not Agree & 12 & 12,0 & 7 & 7,0 \\
\hline \multicolumn{5}{|c|}{ Pregnancy gymnastic } \\
\hline Agree & 37 & 37,0 & 65 & 65,0 \\
\hline Not Agree & 63 & 63,0 & 35 & $3,5,0$ \\
\hline \multicolumn{5}{|c|}{ Pregnancy Examination } \\
\hline Agree & 78 & 78,0 & 99 & 99,0 \\
\hline Not Agree & 22 & 22,0 & 1 & 1,0 \\
\hline \multicolumn{5}{|c|}{ Wanted pregnancy } \\
\hline Agree & 88 & 88,0 & 92 & 92,0 \\
\hline Not Agree & 12 & 12,0 & 8 & 8,0 \\
\hline
\end{tabular}


and abstinence in pregnancy. This needs special attention since there might be a misperception to the media, align with Ibrahim's (2013) study stating that the success of the counselor or premarital and genetic preparation educator in providing positive counseling to the bride and groom candidate are influenced by the basic knowledge and skills concerning the theory and practice of counseling and interview skills as well as interventions conducted in Jeddah, thus training of prior knowledge and expertise in pre-marital preparation are required (Ibrahim et al., 2013). In addition to educator, the duration of time in the pre-marital course enables the presence of negative attitudes related to reproductive health because humans need about 3 weeks to adapt to changes (Lally, 2010).

The success of the pre-marital course in Brebes District, one of them through booklet media, is aligned with the result of the study that with the use of media minimize the difference of interpretation (Mutmainah et al., 2014), besides graphics media and game stimulation method can support the premarital counseling implementation and adolescent reproductive health improvement ( Ibrahim et al., 2011; Rizki, 2012). It is necessary to follow up in the form of pre-marital education which can be presented massively through other media such as television, radio and magazine so that the purpose of saving mother and baby can be achieved equally, through interesting media that can increase the interest of respondents up to 65\% (Al-Aama, 2018, Al-Aama, 2008). Comprehensive program for bride and groom candidate previously is applied by developed countries. The government requires the bride and groom canditate to receive premarital education and reproductive and genetic health examination (Ibrahim et al., 2011, Serjeant et al., 2017).

\section{Conclusion}

The intervention of pre-marital preparation education for bride and groom candidate has significant influence in improving knowledge and attitude, therefore it will improve the quality of information transfer (transfer of knowledge), public health status monitoring, particularly in the effort to save mother and baby, MMR and IMR decrease, achievement of Family Planning, improving the quality of family life, improving understanding and knowledge regarding family life in the build of sakinah, mawaddah, warrahmah family and reduce the number of dispute, divorce, and domestic violence. The results of the study can be used as a policy recommendation (public policy brief) related to the program of Premarital Course.

Advised recommendations are premarital course socialization by KUA officers is expanded and the booklet as a tool for the KUA officers to implement pre-marital course is multiplied. For the Diponegoro University Public Health Faculty and other Institutions related to mother and child health, there needs to be continuous research on counseling and media distribution in other forms related to pre-marital preparation and reproductive health of the bride and groom, as well as media content improvement.

\section{Acknowledgment}

The authors thank the staffs of the Office of Religious Affairs Brebes District, all respondents who helped to complete this research and especially to the Institute of Research and Community Service Diponegoro University who have facilitated this research.

\section{References}

Al-Aama, J.Y., 2018. Attitudes Towards Mandatory National Premarital Screening for Hereditary Hemolytic Disorders. Health Policy, 97(1), pp.32-37.

Al-Aama, J.Y., Al-Nabulsi, B.K., Alyousef, M.A., Asiri, N.A., \& Al-Blewi, S.M., 2008. Knowledge Regarding the National Premarital Screening Program among University Students in Western Saudi Arabia. Saudi Medical Journal, 29(11), pp.1649-53.

Al-Azeem, S.T.A., Elsayed, E.T., Sherbiny, N.A.E.K.E., \& Ahmed, L.A.E.G., 2011. Promotion of Knowledge and Attitude towards Premarital Care : An Interventional Study among Medical Student in Fayoum University. Journal of Public Health, 3, pp.121-28.

Al-Sulaiman A., Suliman, A., Al-Mishari, M., Al-Sawadi, A., \& Owaidah, T.M., 2008. Knowledge and Attitude toward the Hemoglobinopathies Premarital Screening Program in Saudi Arabia: Population-Based Survey. Hemoglobin, 32(6), pp.531-538.

Alswaidi, F.M., \& Sarah J.O., 2009. 
Premarital Screening Programmes for Haemoglobinopathies, HIV and Hepatitis Viruses: Review and Factors Affecting Their Success. Journal of Medical Screening, 16(1). pp.22-28.

Azinar, M., 2013. Perilaku Seksual Pranikah Berisiko Terhadap Kehamilan Tidak Dinginkan. Jurnal Kesehatan Masyarakat, 8(2), pp.15360.

Brixval, C., Axelsen, S., Thygesen, L., Due, P., \& Koushede, V., 2016. Antenatal Education in Small Classes May Increase Childbirth SelfEfficacy: Results from a Danish Randomised Trial. Sexual \& Reproductive Healthcare, 10, pp.32-34.

Giarratano, G., Sterling, Y.M., Orlando, S., Mathews, P., Deeves, G., Bernard, M.L., \& Danna, D., 2010. Targeting Prenatal Emergency Preparedness Through Childbirth Education. Journal of Obstetric, Gynecologic, \& Neonatal Nursing, 39(4), pp.480-88.

Ibrahim, N.K, Bashawri, J., Al-Bar, H., Al-Ahmadi, J., Al-Bar, A., Qadi, M., Milaat, W., \& Feda, H., 2013. Premarital Screening and Genetic Counseling Program: Knowledge, Attitude, and Satisfaction of Attendees of Governmental Outpatient Clinics in Jeddah. Journal of Infection and Public Health, 6(1), pp.41-54.

Ibrahim, N.K., Al-Bar, H., Al-Fakeeh, A., AlAhmadi, J., Qadi, M., Al-Bar, A., \& Milaat, W., 2011. An Educational Program about Premarital Screening for Unmarried Female Students in King Abdul-Aziz University, Jeddah. Journal of Infection and Public Health, 4(1), pp.30-40.

Mutmainah, V.T., Nugraheni, S.A., \& Suparwati, A., 2014. Analisis Perbedaan Implementasi Program Suplementasi Tablet Besi Ibu
Hamil Oleh Petugas Gizi Antara Puskesmas Cakupan Tinggi Dan Rendah Di Wilayah Kabupaten Kendal Healthcare Center in Kendal. Manajemen Kesehatan Indonesia, 2(2), pp.140-49.

Kementerian Kesehatan RI, 2017. Profil Kesehatan Indonesia. Pusat Data dan Informasi Kementerian Kesehatan Republik Indonesia. Jakarta.

Keshavarz, A., Amrgha, H.A., \& Melatkhah, N., 2013. Effectiveness of Marriage Education Before Marriage Change Irrational Beliefs Girls. Procedia-Social and Behavioral Sciences, 84, pp.520-524.

Lally, P., Jaarsveld, C.H.M.V., Potts, H.W.W., \& Wardle, J., 2010. How Are Habits Formed: Modelling Habit Formation in the Real World. European Journal of Social Psychology, 40(6), pp.998-1009.

Rizki, N.A., 2012. Metode Focus Group Discussion Dan Simulation Game Terhadap Peningkatan Pengetahuan Kesehatan Reproduksi. Jurnal Kesehatan Masyarakat, 8(1), pp.23-29.

Serjeant, G.R, Serjeant, B.E., Mason, K.P., Gibson, F., Gardner, R., Warren, L., \& Jonker, M., 2017. Voluntary Premarital Screening to Prevent Sickle Cell Disease in Jamaica: Does It Work? Journal of Community Genetics, 8(2), pp.133139.

Smith-Greenaway, E., 2016. Premarital Childbearing in Sub-Saharan Africa: Can Investing in Women's Education Offset Disadvantages for Children?. SSM-Population Health, 2, pp.164-74.

Wijaya, I.M.K., Agustini, N.N.M., \& Tisna, G.D.M.S., 2014. Pengetahuan, Sikap Dan Aktivitas Remaja Sma Dalam Kesehatan Reproduksi Di Kecamatan Buleleng. Jurnal Kesehatan Masyarakat,10(1), pp.33-42. 